\title{
THE STRUGGLE FOR EDUCATION IN NORTHWEST IOWA: UNIVERSITY OF THE NORTHWEST 1889-1895.
}

\author{
By Robert L. MeDonald \\ Sioux City, lowa
}

Mr. McDonald is a student at Morningside College in Sioux City, Iowa. The following paper was originally presented by Mr. McDonald to the historical society of the North Central Jurisdiction of the Methodist Church, meeting at Mt. Pleasant, Iowa, June, 1967.

The Northwest Iowa Conference of the Methodist Episcopal Church was created in 1872 . The need for an educational institution within the conference boundaries was expressed early.

The conference gave its support, starting in 1881; to Cornell College at $\mathrm{Mt}$. Vernon in the Upper Iowa Conference. Cornell remained the official conference college until 1895.

However, a college within the Northwest Iowa Conference was still sought so that young people in the area would not be "lost" to other schools.

At the annual conference meeting in 1887 three locations were suggested as possible sites for a college: Ida Grove, Storm Lake, and Sioux City. Most members of the conference were in favor of one of the first two because they believed a city would exert a bad moral influence on the students. Those who favored Sioux City were able to get the decision postponed for a year.

The 1889 conference adopted the following resolution: "Resolved, That a Commission consisting of two ministers and two laymen from each District, and the Presiding Elders, be chosen by this Conference to receive bids for an educational institution or institutions to be established somewhere within

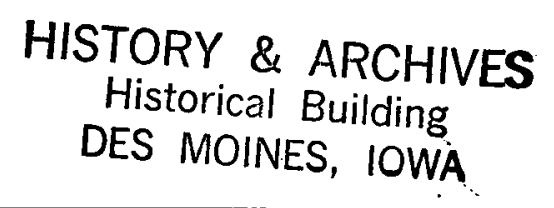


the bounds of our Conference . . . with the full understanding that we will not sanction the establishment of. a school of high grade unless there be guaranteed a suitable campus, and in securities $\$ 500,000$, accredited guarantees to accompany each bid." The commission was appointed.

Prominent businessmen of Sioux City wanted to build a university. The Rev. R. C. Glass, Methodist minister in Sioux City, and the Rev. Wilmot Whitfield, presiding elder of the Sioux City district persuaded these men to organize the university to gain the support of the Northwest Iowa Conference.

The institution, known as the University of the Northwest, named after the conference, was organized that fall. The Articles of Incorporation were drawn up Dec. 27, 1889, and filed with the county recorder Jan. 14, 1890. The signatures affixed to the articles were those of the Rev. Wilmot Whitfield, J. F. Hopkins, James A. Jackson, the Rev. R. C. Glass, Edward Todd, E. C. Peters, George Eisentraut, Arthur S. Garretson, the Rev. Ira N. Pardee and Ed Haakinson. Of these, the Rev. Whitfield and the Rev. Pardee were members of the conference committee which was to locate the educational institution. The Rev. Glass was also a member of the conference committee. All the others were members of the Methodist Episcopal Church, except Mr. Jackson, Mr. Peters, Mr. Garretson and Mr. Haakinson.

The Rev. R. C. Glass, one of the incorporaters, described the difficulties in locating the University of the Northwest within Sioux City:

"From the first it was pretty well settled that it should be on the Morning Side section of the city, although some inducements were held out to locate on the north end and also on the west side.

But when the committees were well nigh discouraged over the effort, the present site was finally determined by a conference between Mr. E. C. Peters and myself one evening

${ }^{1} J o u r n a l$ and Reports of the Seventh Annual Session of the Northwest Iowa Conference of the Methodist Episcopal Church, Cherokee, Iowa, 1878 , p. 38 . (Hereafter referred to as Minutes.) - 
at my house on Morning Side. . . when we concluded that all things considered that was the most eligible site and if we held firmly to that decision the other members would be brought to see it as we did, which resulted a few days later. I doubt if anybody afterwards seriously considered that a mistake was made at that point."

No less than a university would be expected at this time. These were boon times when Sioux City built an elevated railroad which was soon electrified; a corn palace was decorated annually. Sioux City promoters ran special trains to Boston and other eastern cities, brought eastern capitalists to Sioux City, and convinced them that their investments in this growing city would reap fantastic returns.

The University of the Northwest decided to follow the general plan of Northwestern University in Evanston. According to this plan, the University would acquire large amounts of land near the campus by gift or otherwise. The location of the University would increase the value of the land, and the sale of the land would give the University an income. The plan seemed wise, and during the first eight months $\$ 50,000$ worth of such property was sold.

The great optimism fostered by the booming economy was reflected in the organization of the University. Article XIV of the Articles of Incorporation listed the colleges that would make up the University of the Northwest. These included a preparatory department, a normal department, a conservatory of music and art, and departments of agriculture, classics, commerce, domestic economy, home education, higher literature, law, medicine, technology, and theology. ${ }^{3}$

That the University of the Northwest was organized with the hope of gaining the support of the Northwest Iowa Conference is shown by some of the Articles of Incorporation:

"Art. VI. The incorporators of this university, and assigns or successors shall constitute a board of managers, a majority of whom shall be members of the Methodist Episcopal Church in good and regular standing. . . 1909.

${ }^{2}$ Letter from the Rev. R. C. Glass to Prof. E. A. Brown, Mar. 15,

${ }^{3}$ Minutes, Ft. Dodge, Iowa, 1891, pp. 36-37. 
Art. VII. The board of managèrs shall elect and maintain the president of the university. He shall be a member of the Methodist Episcopal Church.in good and regular standing; and he shall be continued in office five years. ..."

The Rev. Wilmot Whitfield was elected the first president of the University of the Northwest.

Construction began in the spring of 1890 on the School of Technology, the first building on campus. It was expected to be completed by fall.

During the summer of 1890 a faculty was assembled for the fall term. The list was, impressive, including the Rev. R: C. Glass as Dean of the College of Liberal Arts; F. M. Harding as Dean of the College of Commerce; George W. Beggs as Dean of the Medical College; the Rev. J. C. Gilchrist as Dean of the College of Didactics; Edwin J. Stason as Acting Dean of the College of Law; and Mrs. Emilie Mallory as Director of the Conservatory of Music.

The Catalog of the University of the Northwest for 18901891 listed seven colleges. The listing of courses offered is further evidence of the prevailing optimism of the time. The College of Liberal Arts offered four different general courses: the classical, the philosophical, the scientific, and one in modern literature. These courses were for four years of three terms each. Tuition was $\$ 12$ per term. The Preparatory Department offered introductory courses in these same fields. The courses were for three years: tuition was $\$ 9$ per term. The College of Commerce had four terms per year. Courses were offered in bookkeeping, penmanship, commercial law, economics, shorthand, typewriting and other skills necessary for business. Tuition was $\$ 15$ per term. The College of Didactics offered a four-year course of four terms each; tuition was $\$ 10$ to $\$ 12$ per term. The College of Law had a two year course with three terms each; tuition was $\$ 50$ per year or $\$ 20$ per term. The Conservatory of Music offered six different general courses: The History of Theory of Music, The Voice, The Piano, The Organ, The Orchestra; and The Chorus. Expenses varied. The College of Medicine offered three annual sessions of six months each.

${ }^{4}$ Ibid., pp. 35-36. 
Arrangements were made for opening the College: of Law and the College of Commerce in business blocks downtown. The College of Medicine was "temporarily" located in a residence at 1712 Garretson Ave: A. medical building. and hospital were to be built on the campus. butwwere never constructed. The Medical College was later located in a business building downtown. The Conservatory of Music was also located downtown. The work of the College of Didactics, the Preparatory Department, and the College of Liberal Arts were carried on at the campus in. Morningside.

The College of Didactics opened Sept. 9, 1890, a week before the College of Liberal Arts and the Preparatory School. The building on campus was not completed, so registration and early classes were held at Grace Methodist Episcopal Church at the northwest corner of Orleans and St. Mary's Avenues. On the day of registration Professor E. A. Brown went to the church and found two "timid maidens," one not sure she wanted to stay. The University was coeducational from the beginning. Mr. McClellan Davis of Sergennt Bluff was probably the first of about 50 students to register. Other students came later. A bulletin in the spring of 1891 gave the enrollment as 251 students for the first year. ${ }^{5}$ The first chapel service, conducted by Dean Gilchrist, had 15 persons in attendance; it was later discovered that two of these were visitors.

The College of Commerce opened on September 1, the Colleze of Law on September 13, and the Conservatory of Mussic on September 22.

: The catalog for 1890-1891 gave this advice for students coming to the campus:

' "Students arriving in the city should keep their checks for baggage, take the Electric cars on Fourth Street, for the Union Stock. Yards and then the Motor Line near the Stock Yards to the University at Morningside. There they will be

${ }^{5}$ E. A. Brown, "Historical Sketch of the University of the Northwest and Morningside College, Sioux City, Iowa," unpublished MS, Archives, Morningside College, Sioux City, Iowa, 1930, p. 12:" 
welcomed by the President or some other member of the faculty and given such information and counsel as may be needed."

The campus was described as follows:

"The University of the Northwest is located on beautiful grounds on Morningside, the most delightful suburb of Sioux City, from which a commanding view is had of the city and surrounding country. . .

The University is reached from the city by the elevated railway, and ere long the Morningside extension of the electric railway run to the campus."”

The electric railway ran by Peters Park, only three blocks south of the campus. An extension which ran from Peters Park north and skirted the campus was not completed until 1897.

The religious position of the University of the Northwest and its code of conduct were described in that early catalog in these words:

"While this institute is under the fostering care of the Methodist Episcopal Church, it is free from sectarianism, and will be conducted on broad christian principles. .

"We therefore require of all our students to attend upon the religious services at the chapel at the opening of each school day, and on the Sabbath morning services of such church as they, or their parents or guardians may select. Also on the Sabbath numerous bible classes will be conducted by members of the Faculty at which the students are earnestly counseled to be present. ${ }^{8}$

"We believe that the best government is self government. Hence the institution has no long code of rules, but only a few simple requirements that will commend themselves to all right minded persons. . . the visiting and association of ladies and gentlemen is strictly forbidden, except at such times and under such regulations as the Faculty may deem wise.

${ }^{6}$ Catalogue of the University of the Northwest, 1890-1891, Sioux City, Iowa: University of the Northwest, 1890, p. 26.

${ }^{7} I$ bid., p. 5.

${ }^{8}$ Ibid., pp. 5-6. 
"Everything in deportment which interferes with the highest mental and moral development of the student is prohibited, such as profanity, obscenity, gambling, the playing of cards and billiards, the use of intoxicating liquers, and all forms of dissipation. The use of tobacco in the buildings or upon the grounds of the University is forbidden. This is required because of the presence of ladies and others to whom it is offensive and because the habit is expensive, as well as uncleanly, and detrimental to health."

Finances are another important facet of higher education. The tuition as previously noted differed among the various colleges. Board was $\$ 2.25$ per week at the dining hall. The catalog described the rooms available:

"Rooms furnished with bedstead, bed spring, mattress, commode, toilet sets, chairs, table and carpet will be rented to each of two students for prices ranging from 50 cents to $\$ 1.00$ per week, according to location. . . Board and neatly furnished rooms in private families will range in price from $\$ 2.75$ to $\$ 3.50$ per week. Students who board themselves can still further reduce the cost of living."10

A second building on campus was started; the cornerstone was laid Sept. 9, 1890. The foundation cost $\$ 30,000$, but after it was completed work stopped for several years.

The founders and backers of the University of the Northwest, seeking financial support, appeared before the Northwest Iowa Conference, meeting in Spencer in September, 1890. The Rev. I. N. Pardee presented a statement about the progress of the University, and the conference adopted a resolution that provided for the Bishop to appoint a Cabinet to supervise financial and other concerns of the institution. The conference recognized the University to the extent that Bishop Fowler appointed the Rev. Wilmot Whitfield as Chancellor, the Rev. R. C. Glass to a professorship, and the Rev. I. N. Pardee as financial agent.

The first campus newspaper, a four-page monthly called the University Graphic, first appeared in December, 1890,

${ }^{9}$ Ibid., p. 6.

${ }^{10}$ Ibid., p. 6. 
with W. A. Campbell as editor. The first issue showed pictures of proposed buildings for the campus. The following editorial. appeared in the first issue:

"The regents and faculty, evidently with no other object than the founding of an institution second to none in the West, are so imbued with the spirit and importance of the work that the students have caught and imbibed some of this feeling, and in order that they may be advanced with the other educational work and not be behind in anything, have determined to send forth at the end of every month a messengerthe Graphic - as their medium of communication." ${ }^{11}$ The second issue of the Graphic, January, 1891, was Vol. 1, No. 1, perhaps because of the change of editors. Vincent E. Sawyer was the new editor. The Graphic was only published for a year. Other student newspapers published at the University of the Northwest included the Boomerang, by the Othonian Literary Society, and The Wave.

The University suffered its first major financial difficulties in December, 1890. After that it was always difficult to keep. going. This was the beginning of a lengthy financial struggle, though no one expected the economic problems to last long. The backers of the University gave their own money to tide the institution over until better times; the Rev. Glass and the Rev. Whitfield both gave their entire small fortunes.

Grace Methodist Episcopal Church was not well adapted. for college work. There was little or no scientific apparatus. However, since the classes were small and few, the building served fairly well. Classes were held there until the end of the first term in December.

The first building on campus, the School of Technology, was completed in January, 1891, and classes started there at the beginning of the second term. The four-story building, measuring $43^{\prime} \times 65^{\prime}$ and built of Minnesota quartzite granite, including furnishings cost $\$ 36,000$. The chapel on the third floor had benches and a platform with a discarded grand piano and two hanging kerosene lanterns. The second floor

${ }^{11}$ Mary Alice Hollman, "University of the Northwest," The Sioux 1909, p. 109. 
was given over to living quarters for some of the faculty and students. The classrooms were on the first floor. The physics laboratory, with what little scientific apparatus was available, was located there. There was also a so-called library; it contained no reference books, not even a dictionary, but only some outdated textbooks bearing the name of J. C. Gilchrist. The girls' cloakroom was eventually converted into a classroom. The basement contained the kitchen and the dining hall. There were no outside steps at the front of the building; the stones, designated for that purpose, were lying around on the ground. There was a set of rickity wooden steps at the back.

A bell in the tower rang at 6:00 a.m. to get students up for a 7:00 breakfast. This was followed by a chapel service before the day's classes began. The same bell rang at 10:00 p.m. to signal the hour for retiring.

The first graduating class, in the spring of 1891, included William Jepson, of Sioux City; Herbert W. L. Mahood, of Sioux City; J. B. Trimble, of Odebolt; and Thomas F. Warner, of Postville. These students had completed most of their college course before coming for their final year at the University of the Northwest.

The backers again approached the Northwest Iowa Conference, meeting in Ft. Dodge in 1891. The situation was well summarized by the Rev. Bennett Mitchell:

"Like the camel in the fable, it got its nose into our tent last year, and this year it sought to come in bodily, loaded down with a debt of over one hundred thousand dollars, while all the real estate to which it had any title was loaded down with first and second mortgages calling for amounts far exceeding any reasonable valuation. Besides this it had some equities which depended for their value on the sale of lots and other property at fabulous prices. But its name "The University of the Northwest' was. high sounding and its pretentions were great. ...Why, it looked as if it were soon. to rival Yale. The conference was captured, and we said: ${ }^{12}$

"Whereas, .This conference has given its endorsement to

${ }^{12}$ Bennett Mitchell, History of the Northwest Iowa Conference, 1872-1903, Sioux City: Perkins Bros. Co., 1904, pp. 183-184. 
the establishment of the University of the Northwest; therefore,

Resolved, lst. That we give to it our earnest support and will endeavor to secure for it the highest success and efficiency.

Resolved, 2nd. That we will encourage the attendance upon this school of such of our young people as are more convenient thereto, than to other schools.....

Resolved, Further, That we welcome to our respective charges the representatives of Cornell College and the University of the Northwest in the prosecution of their work."13

A second resolution concerning the University was also adopted at that annual conference. It granted the same privileges to the University of the Northwest as to any other schools having the patronage of conference. It also stated that if Art. VI of the Articles of incorporation were amended to change the size and powers of the University's Board of Managers, the Northwest Iowa Conference would become one of the patronizing conferences of the University of the Northwest.

The first resolution pledged support but none of the conference's money for the University. The second one, which hinted at financial support, did not go into effect because the amendments were evidently not implemented. According to the Rev. Bennett Mitchell:

"There were, however, articles purported to be amendments to the original articles, placed on record in the county clerk's office in December of this year. But they were never properly acknowledged so as to give them legal effect. The Conference continued to elect members to the board of control and a visiting committee and a financial agent, and to recommend the appointment of a member of the Conference to the presidency of the school and others to professorships." ${ }^{14}$

At this time several literary society were organized. The Aeromathean society was organized in June, 1890. The

${ }^{13}$ Minutes, Ft. Dodge, Iowa, 1891, p. 25.

${ }^{14}$ Mitchell, op. cit., pp. 185-186. 
Othonian literary society for men was organized Nov. 7, 1891, and the Atheneum society for women students was formed a week later. The Ionian society was also organized during the first two years. The Philomathean society was organized on Oct. 14, 1892; at first it was for both men and women, but after its first year it became a men's literary society. Some of these societies disappeared after a year or two; others were still in existence many years after the University of the Northwest had disappeared from the scene.

The conditions on the campus were not satisfactory. This petition from about 25 students, dated June 22, 1892, and addressed "To the various Boards of the University of the Northwest," makes light of several problems. It says in part:

"We the undersigned students of the Un-N-W having an interest in the welfare of the University and wishing to see it prosper desire to make a few statements which we believe should be made for the welfare of the school.

1. During the past year we have had no sidewalks and have been compelled to wade through mud a large portion of the time to reach the University building.

2. Our physical health has been endangered on account of the extreme coldness of the building; to consequence of which classes were dismissed a number of times and on some occasions the whole school was adjourned as the building was too cold for students or instructors.

3. We have no library to aid us in our work.

4. We have but one water-closet for both sexes and that one unfavorably located.

5. We have no cloakrooms.

6. We have no study-room or any convenience for study in the building.

7. We have no apparatus for the teaching of physical sciences.

8. It being necessary frequently to attend night meetings of our societies we have been greatly inconvenienced by having no lights upon the school grounds."

${ }^{15}$ Thomas E. Twieto, "A College in a Cornfield," Morningside Through Fifty Years: Morningside College Bulletin, XXVIII, September, 1944, pp. 4-5. 
But life was not all hard work and drudgery. Students can always find ways to amuse themselves. On moonlit winter nights students and faculty could be seen coasting down Davis Hill east of the campus. Skating on Half Moon Lake, a mile west of the campus, was another popular winter activity. The literary societies had their own annual programs, called publics. These consisted of orations, recitations, musical solos and groups.

By the summer of 1892 , the Rev. Whitfield had put $\$ 26,000$ of his own money into the University of the Northwest and asked to be released from the presidency because the financial pressure was too great. The Rev. William Brush was elected the new president.

The report of the Education Committee to the Northwest Iowa annual conference of 1892 said in part:

"The management is to be congratulated upon the enrollment of some 200 students during the past year, in all departments, and we note with pleasure that the graduates take high rank in their various fields of labor. The enrollment for the present year is a large improvement over that of the same time a year ago."16

The graduation class in the spring of 1893 consisted of Ed Mahood and James H. O'Donoghue.

The annual conference. met at Grace Methodist Episcopal Church in Sioux City in September, 1893. The net assets of the University of the Northwest were reported at the 1892 conference as $\$ 300,400$. The following year the assets totaled $\$ 107,000$ - nearly $\$ 200,000$ less than the previous year. The liabilities remained about the same for those two years. The net decline was caused by the decline in value of land held by the University.

Miss Lillian E. Dimmitt, one of the instructors at the University, summed up the situation in September, 1893, as follows:

"The University of the Northwest was not a Methodist School. The Northwest Iowa Conference had nothing to do with it and no responsibility for it. The original sponsors and promoters had lost all and had no further interest in it.

${ }^{16}$ Minutes, Cherokee, Iowa, 1892, p. 25. 
There were, however, a few Methodists on the Board of Management, the Board of Regents, and the Executive Committee, who were interested in the continuance of the school until the Northwest Conference, which favored the college, would come to a decision as to the location of it."17

The University of the Northwest fell with all the rest of Sioux City's boom-financed projects. The years $1893-1895$ were the worst for the University. It borrowed money till credit was gone; credit became so bad that an order for a single pane of glass was refused.

Conditions were so bad that the students rose in revolt. A group of students delivered a protest to the board of managers in session. One manager wrote this hasty note on a sheet of wrapping paper to the leader of the demonstration: "For God's sake, ----, stay by us and we will see that you get things better some how!"18

The academic year 1893-189 \& was the "heroic age" of the students and faculty who remained with the University. Three University students organized a lecture course. They secured lecturers and entertainers who would donate their services, and the students sold tickets to the residents of Morningside. The proceeds went for having the steps erected in front of the University building and getting an unabridged dictionary for the "library." In the spring of 1894 the students transplanted trees from the wooded area on the west side of the campus to the front of the campus and planted them in groups and rows. The faculty paid heavy bills from light receipts and tried to live on the remainder. The landlady and head of the dining hall left. The dining hall was taken over by the faculty; the women prepared the food, and the men washed the dishes. Most of the faculty left; only two professors and a few instructors remained. One student is recorded to have said, as many, undoubtedly, felt: "We didn't know when we left school one day whether there would be

${ }^{17}$ Lillian E. Dimmitt, "Reminiscences of Miss Lillian E. Dimmitt," part 3, The Morningsider, June, 1966, p. 4.

${ }^{18}$ Sidney L. Chandler, "The History of Morningside College," The Sioux 1913, p. 12.

10"History of Our College," Blue and White 1901, p. 10. 
any school to go to the next." Edward M. Corbett was the only graduate in the spring of 1894 . Commencement was held in the chapel on the third floor of the University building.

The 1894 session of the Northwest Iowa Conference adopted this resolution:

"WHEREAS, It is important that an educational institution be maintained at Morning Side, Sioux City, under the control and management of this Conference, and

WHEREAS, There seems to be a serious danger that this cannot be done through the agency of the University of the Northwest: therefore

Resolved, that the committee on education be requested to take into consideration the feasibility of the appointment by the Conference of a commission with full power and authority to establish a college or Conference Seminary at that place, according to the judgment on said commission as to the necessity and practicability thereof. .."20

The Committee on Education, in answer to the resolution, recommended that a commission of 15 members of the conference, under the leadership of the Rev. G. W. Carr, be appointed and have the power to establish a college in Sioux City or elsewhere within the conference. The commission should include itself in the trustees of the new institution and elect the Rev. Carr as president.

Bishop Fowler selected the following members of the conference for the commission: G. W. Carr, president, W. F. Gleason, Robert Smylie, F. E. Day, L. H. Woodworth, Bennett Mitchell, J. B. Trimble, J. W. Lothian, D. M. Yetter, George W. Pratt, H. K. Hastings, W. A. Black, G. W. L. Brown, Joal A. Smith and Robert Bagnell. This group, with the exception of the Rev. Smith, met Dec. 5, 1894 at the First Methodist Episcopal Church in Sioux City. The Rev. G. W. Carr later reported about that meeting:

"After carefully considering all our Conference educational needs and interests, and in accord with the authorization of the Conference, the Commission proceeded to 'duly and

${ }^{20}$ Minutes, Webster City, Iowa, 1894, pp. 26-27. 
legally incorporate' an educational institution. Under the name and title of Morningside College such was thereupon duly authorized and chartered." 21

Associating themselves with the following laymen the commission named themselves as members of the Board of Trustees of Morningside College: Hon. J. P. Dolliver, J. R. Atwood, J. G. Shoemaker, Hon. P. A. Sawyer, Samuel Parker, E. C. Peters, A. M. Jackson, J. C. Button, Hon. E. S. Ormsby, J. P. Negus, H. C. Warner and J. L. Bleckly. The Rev. Carr was elected president of the college and financial agent with a salary of $\$ 1200$ per year plus traveling expenses. The Rev. Bennett Mitchell was elected president of the board of trustees. The name Morningside College was at first considered to be only temporary.

By this time the University of the Northwest had ceased to exist; the property went into the hands of the sheriff. Some of the colleges became separate institutions, such as the Sioux City Medical College. Others passed from the scene.

The Rev. Bennett Mitchell, a long-time member of the Northwest Iowa Conference, made this comment about the closing of the University: "It should here be noted that our Conference never in any true sense became the sponsor of the institution. We did, however, foolishly dabble with it so that the public regarded its failure as our failure. The whole affair was a colossal blunder." ${ }^{22}$ The Rev. R. C. Glass expressed a different view about the University's short existence; he believed that the institution failed because it fell victim to the difficult economy of the times. ${ }^{23}$

The new directors of Morningside College met June 11, 1895. Prof. O. A. Schotts was elected Dean of the faculty. The campus property of the University of the Northwest could be purchased for $\$ 25,250$. This property included the campus of sixteen and a half acres, the one building and the foundation of the second, which was at that time overgrown with weeds. A committee was appointed to purchase the University property and included the Rev. Carr, H. L. Warner, P. A.

${ }^{21}$ Minutes, LeMars, Iowa, 1895, p. 26.

${ }^{22}$ Mitchell, op. cit., p. 186.

${ }^{23}$ Glass, letter, op. cit. 
Sawyer and A. M. Jackson. The Rev. J. B. Trimble mortgaged a small farm in Calhoun County for $\$ 2,500$ to help raise the $\$ 4,000$ by September.

Edwin Lawrence Benedict and F. W. Plondke, in the classical and scientific courses respectively, were the first graduates of Morningside College. They received their entire education at the University of the Northwest. Morningside College was in the unusual position of holding its first graduation exercises before it opened classes.

Classes first opened at the new institution on Sept. 11, 1895, with 196 students. On this date Morningside College had only one building and the foundation of another, overgrown with weeds. It also had to live with the reputation of its predecesser which had failed. There was a great deal of work ahead before she could hold her head high among her sister institutions. But she had a new name, a new charter, and the support of a Christian Church.

\title{
A PIONEER IOWA FARMER: JOHN ADAM SCHULER, 1853-195i
}

\author{
Submitted by \\ Edgar A. Schuler \\ Professor of Education and Sociology \\ Michigan State University
}

John Adam Schuler was born in Muscatine, Iowa in 1853. At the age of 24 he moved to Garner, Iowa, and began farming. The contents of the following article, which was dictated and edited by John Schuler in 1937-38, range from the dangers of being a landlord to the cause of the Great Depression.

\section{Part I}

In 1870 I left my home at Fond du Lac, Wisconsin, and went to Milwaukee as a boy of about 17. I went to work there in a manufacturing plant, making sashes and doors. I worked there for about five years. Wages were very low. Skilled workmen in the factory received $\$ 9$ per week. I spent about $\$ 5$ for room and board and the necessities of life (grand opera was excluded). 
Copyright of Annals of Iowa is the property of State of Iowa, by \& through the State Historical Society of Iowa and its content may not be copied or emailed to multiple sites or posted to a listserv without the copyright holder's express written permission. However, users may print, download, or email articles for individual use. 